\title{
EVALUATION OF THE RELATIONSHIPS BETWEEN NAVIGATION CHANNEL DREDGING AND EROSION OF ADJACENT BEACHES IN SOUTHERN BRAZIL
}

\author{
Lucas Silveira $^{1}$ :Lindino Benedet ${ }^{2}$ : Morjana Signorin ${ }^{3}$ and Rafael Bonanata ${ }^{4}$
}

\begin{abstract}
São Francisco do Sul Harbor, located in the Babitonga Bay, Santa Catarina, is one of the main containership harbors in Brazil and has been in operation since 1955. Due to the increasing demand for ships with greater size and draught, the navigation channel was dredged to $10 \mathrm{~m}$ depth in 1980 and has been gradually deepened to $13 \mathrm{~m}$ in recent years to accommodate Post-Panamax vessels. During the 30 years of dredging operations, more than 10 million $\mathrm{m}^{3}$ of sediments were removed from the coastal system and dumped into an offshore disposal area (about $15 \mathrm{~m}$ water depth), whilst the downdrift beach has experienced severe erosion. The downdrift municipality, Itapoá, recently filed a lawsuit against the Port claiming that harbor dredging has caused much of the erosion observed on its beaches. In order to evaluate the downdrift effects of dredging and maintaining the deep draft navigation channel across the ebb shoal of Babitonga Bay, the Delft3D model was used. The model was calibrated and validated with field data (water level and currents, waves and morphological changes). To evaluate channel impacts on adjacent beaches, 10 years morphology change simulations were conducted for pre-dredging scenario and scenarios of the navigation channel dredged at $10 \mathrm{~m}$ and $13 \mathrm{~m}$ depth, using the dredge and dump tool in Delft3D to maintain the deep draft channel along the simulation. A conceptual model of the sedimentary dynamics of the area was developed utilizing results from numerical modeling and field observations. It was observed in the results that dredging and maintaining the deep draft navigation channel over the last few decades have reduced the amount of sediment bypass by about $13 \%$. Channel dredging has therefore contributed to the erosion of the adjacent beaches, however other man-made interventions on this coastal system that contributed to the erosion problem were also identified (bay closure and tidal prism changes as well as jetties and other structures built updrift). Thus, it cannot be inferred that all the erosion of the downdrift beaches is due to the dredging activities. To mitigate for erosion effects of channel dredging, beneficial sediment disposal strategies were investigated. Strategies evaluated included beach disposal and ebb-shoal disposal of dredged materials. Beach disposal was the alternative that produced direct benefits to the downdrift beach while ebb-shoal disposal produced benefits that were not directly detected on the beach during the time frame evaluated here. Due to benefit-cost considerations, beach disposal was recommended for maintenance operations where dredging volume is greater than $400.000 \mathrm{~m}^{3}$ (about $50 \%$ of the dredging maintenance operations exceed this threshold). For smaller maintenance dredging events, ebb shoal disposal was recommended. This work is the first of this nature in Brazil driven by legal disputes between downdrift beaches and Port authority and sets the precedent for future beneficial use of dredging materials along the Brazilian coast.
\end{abstract}

Keywords: downdrift erosion; sediment disposal; numerical modeling.

\section{INTRODUCTION}

São Francisco do Sul Harbor is located in Santa Catarina State, Southern Brazil, inside the Babitonga Bay (Figure 1). It is one of the main container-ship ports in Brazil and has been operating since 1955. Naturally deep enough in the beginning, the ever increasing draft of the ships has led this port to start dredging activities in 1980 in order to ensure the depth of $10 \mathrm{~m}$ inside the navigation channel. After 20 years, the first deepening dredging took place: In 2000 the channel was deepened to $11 \mathrm{~m}$. Since then it has been gradually deepened in order to accommodate Post-Panamax vessels. It was dredged to $13 \mathrm{~m}$ deep in 2003 and to $14 \mathrm{~m}$ in 2008. Over these 30 years in between deepening and maintenance dredging activities more than 10 million $\mathrm{m}^{3}$ of sediment was removed from the navigation channel and disposed into an offshore dumping area. A better description of the periodicity and volume of sediment removed from the channel at each operation can be seen on Table 1.

\footnotetext{
${ }^{1}$ Shaw Brasil, 8.600, Rod. José Carlos Daux, St. Antonio de Lisboa, Florianopolis,SC,88050-001,Brazil

2 Shaw Brasil, 8.600, Rod. José Carlos Daux, St. Antonio de Lisboa, Florianopolis,SC,88050-001,Brazil

${ }^{3}$ Shaw Brasil, 8.600, Rod. José Carlos Daux, St. Antonio de Lisboa, Florianopolis, SC,88050-001,Brazil

${ }^{4}$ Shaw Brasil, 8.600, Rod. José Carlos Daux, St. Antonio de Lisboa, Florianopolis,SC,88050-001,Brazil
} 


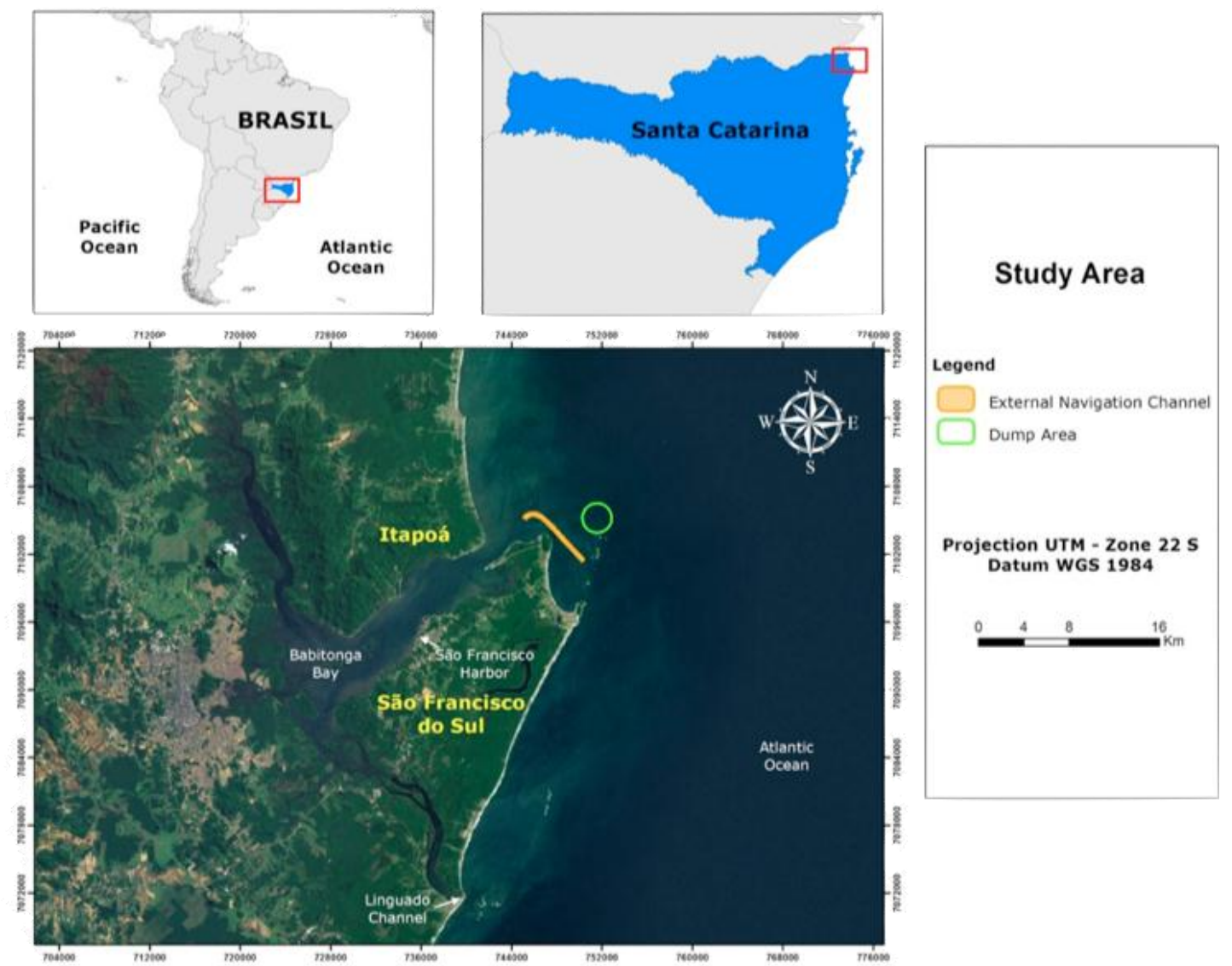

Figure 1. Study area location.

\begin{tabular}{|llll|}
\hline \multicolumn{4}{|c|}{ Table 1: History of São Francisco do Sul Port dredging operations (Source: SFS Port administration). } \\
\hline Year & Type & Volume $\left(\mathrm{m}^{3}\right)$ & Depth $(\mathrm{m})$ \\
\hline 1980 & Initial & $1,564,217$ & 10 \\
1984 & Maintenance & 828,300 & 10 \\
1988 & Maintenance & 293,606 & 10 \\
1991 & Maintenance & 154,675 & 10 \\
1992 & Maintenance & 428,497 & 10 \\
1995 & Maintenance & 383,123 & 10 \\
1997 & Maintenance & 396,706 & 10 \\
2000 & Deepening & $1,168,950$ & 11 \\
2002 & Maintenance & 224,157 & 11 \\
2003 & Deepening & $1,139,056$ & 13 \\
2008 & Maintenance & 426,628 & 12,7 \\
2010 & Deepening & $3,248,644$ & 14 \\
\hline
\end{tabular}

Along with increasing dredging activities, the downdrift beach of Itapoá started suffering from severe erosion. Given the net sediment transport in southern Brazil is in northward direction, by removing such great volumes of sediment from the active transport zone of the beach, the natural bypass rates could have diminished significantly.

LECOST (2002) performed a shoreline evolution analysis by comparing aerial photography from 1957, 1978 and 1995. Results are shown on Figure 2. It is possible to infer that the study area is very dynamic and unstable. Erosion and accretion dominance on morphodynamic processes evolve over time and along the beach domain. Estimate rates of shoreline dynamics for that period are shoreline accretion of $140 \mathrm{~m}$ in between 1957 and 1978 (6.7 m/yr.), and shoreline retreat of $250 \mathrm{~m}$ from 1978 to 1995 (14.7 m/yr.).

A complementary study was conducted five years later by RIO INTERPORT / ACQUAPLAN (2007), using aerophotogrammetry methods (Figure 3). Data from 2006 was included on the analysis. Erosion patterns from 1978 to 1995 were found to have persisted until 2006, although at lower rates 
(100 m, resulting in $9.1 \mathrm{~m} / \mathrm{yr}$.). Isolated accretion zones were also identified on the northern sector of the beach, reaching up to $47 \mathrm{~m}$ of shoreline progradation $(4.3 \mathrm{~m} / \mathrm{yr}$.).

The authors further indicate that there are two distinct zones on Itapoá Beach: southern sector, sheltered from predominant wave action, and mostly affected by ship-generated waves; and the northern sector, composed by oceanic beaches exposed to the wave action. According to Angulo et. al (2006) the most probable cause of the erosion problems is the negative balance in the sedimentary budget induced by the dredging activities on São Francisco do Sul Port. These authors stated that the total deficit along the $16 \mathrm{~km}$ of shoreline is in the range of 100,000 m³/year. The negative sedimentary balance could have influenced not only directly on the volume of sand that reaches the beach, but also on the sea bed morphology of the ebb-shoal and consequently on the way it counter-interacts with the waves and currents. One of these authors, Angulo (1993) found that this same pattern of erosion with similar magnitude developed on some beaches of the State of Parana after the ebb-shoal of Paranaguá Bay was dredged, also for navigation purposes. Encouraged by these papers, the municipality of Itapoá filed a lawsuit against São Francisco do Sul Port claiming that the harbor dredging activities have caused much of the erosion observed on its beaches nowadays, and requesting indemnification for the damages suffered since 1980 .

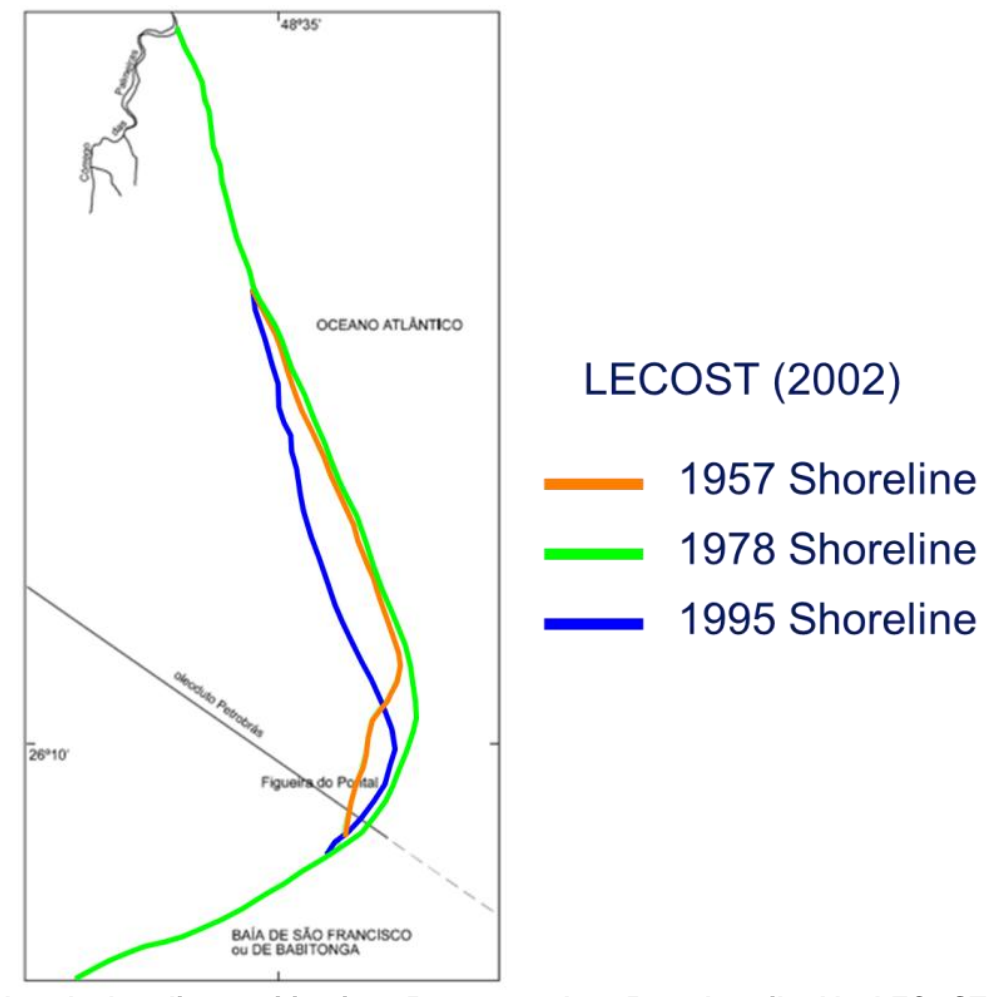

Figure 2. Itapoá beach shoreline position in 1957, 1978 and 1995, as described by LECOST (2002). 


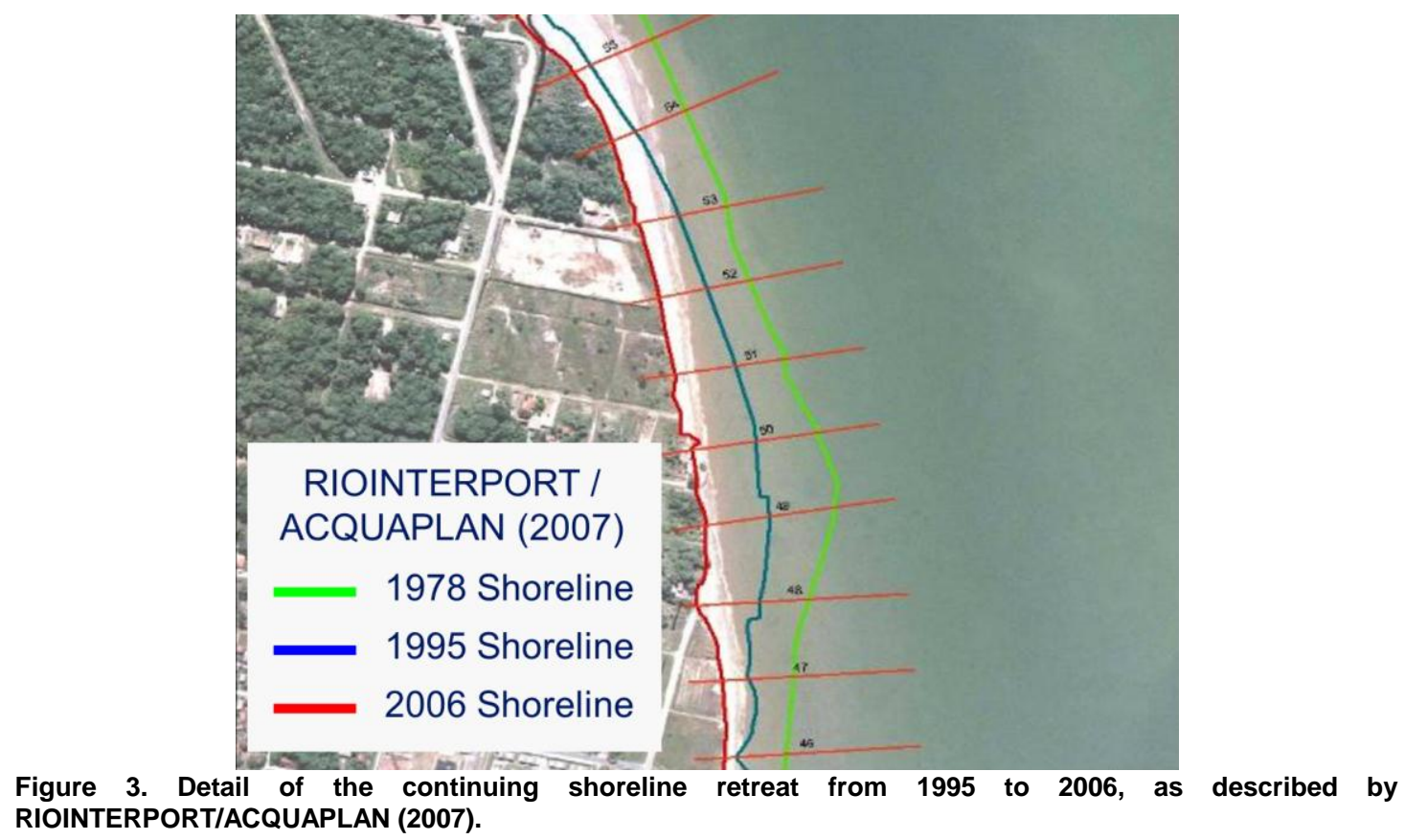

Whether the dredging activities contributed to the erosion problem of Itapoá Beaches, the ebbshoal morphology and the dredging activities alone were not the only changes that happened on the study area during the time frame evaluated. The population of Itapoá Municipality has increased considerably over the last 20 years. According to recent census (IBGE, 2010) the population of Itapoá increased from 4,000 inhabitants to nearly 14,500 inhabitants from 1991 to 2010. That represents a total growth of over $350 \%$ in only 20 years. In addition, Souza (1999) points out that the fast occupation of Itapoá Beaches happened in a much disorganized form. The majority of the frontal dunes were destructed by the new buildings. The infrastructure of the city developed preferably shoreward instead of landwards. Also by having more people living close to the shoreline, the general perception of the erosion is increased. That is when erosion turns into an issue for the population.

Besides the occupation problems, another important detail was left aside during speculations about the possible cause of the erosion. A man-made intervention inside the Babitonga Bay occurred in the 1930's: one of the bay entrances, the so-called Linguado Channel (see Figure 1) was closed with a hydraulic landfill for the construction of a railroad. The Linguado channel inlet, that used to be $800 \mathrm{~m}$ wide, became unstable and started silting up. The morphologic evolution of Linguado Channel inlet from 1862 to 1985 is shown on Figure 4 (INPH, 1985). The closure of Linguado Channel have changed the flow patterns and sedimentary dynamics inside Babitonga Bay (DNIT/IME, 2004).

It cannot be stated that the Linguado channel closure contributed to the erosion on Itapoá Beach, but in the same way it cannot be stated that all the erosion is due to the port dredging activities. Until now, too much has been speculated about the erosion, but little effort has been applied in discovering the possible causes and reasonable mitigation measures for future action. 


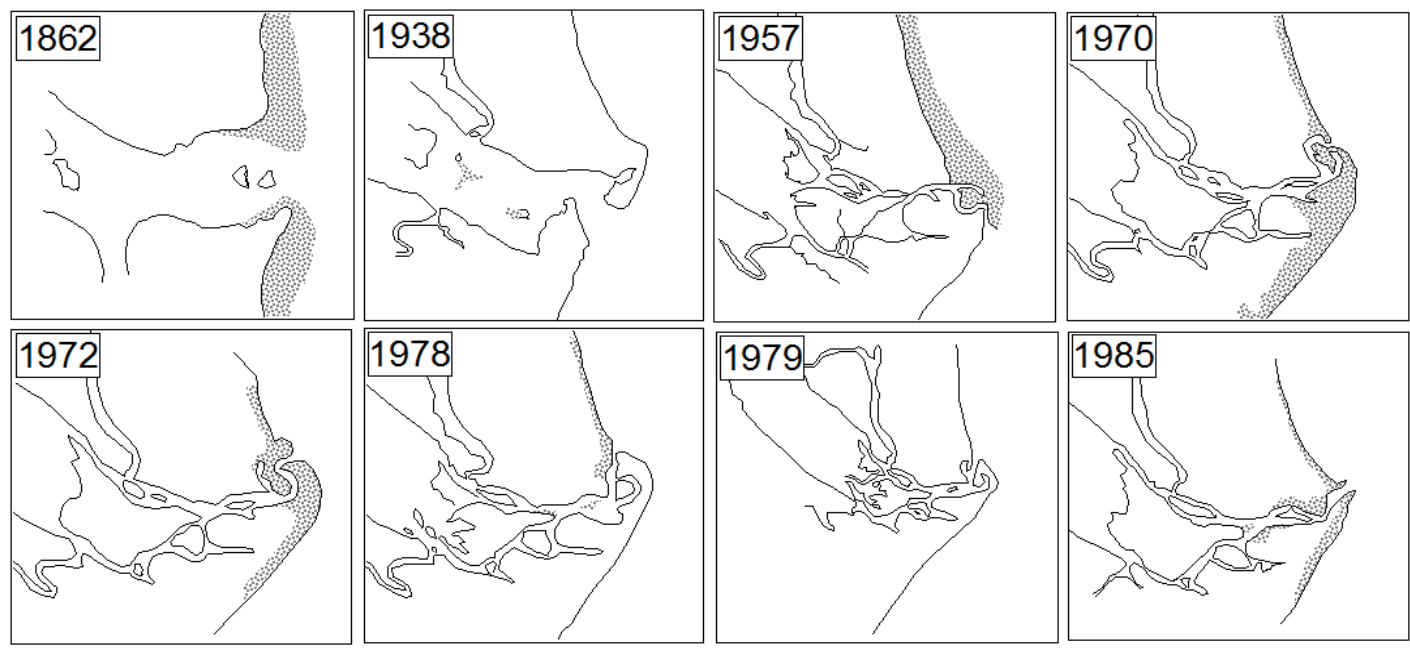

Figure 4. Morphologic evolution of Linguado channel, from 1862 to 1985, as described by INPH (1985).

The purpose of the present study was to evaluate the downdrift effects of dredging and maintaining the deep draft navigation channel across the ebb shoal of Babitonga Bay and to investigate mitigation measures for the erosion problems of Itapoá beaches from beneficial sediment disposal. Methodology involved numerical modeling with the use of the process-based morphodynamic model Delft3D. The scenario previous to dredging activities was reconstructed based on nautical charts of 1941 last updated 1961. Model input data, calibration, and results are presented on next sections.

\section{METHODOLOGY}

The morphologic evolution of Itapoá Beach and Babitonga Bay was evaluated with numerical modeling. The Delft3D modeling package was selected to conduct this study due to its ability to simulate a large number of physical processes in a comprehensive manner, such as wave refraction, wave damping due to bottom friction and whitecapping, wave diffraction, wind stress, tidal flows, longshore currents, the associated sediment transport, and the resulting erosion and deposition. Wave transformation in Delft3D was estimated using the Simulating Waves Nearshore Model (SWAN). Flow, sediment transport, erosion, and deposition within Delft3D were simulated using Delft3D-FLOW 4.00.01. The two models were coupled together, exchanging information with each other every two hours.

The calibration process utilized wave, water level, and current measurements collected by Acoustic Doppler Current Profilers (ADCPs). The sediment transport parameters were calibrated based on erosion/deposition patterns obtained from comparison between two bathymetric surveys from 2005 and 2008.

\section{SOURCES OF INPUT DATA \\ Winds}

The source of wind data was the NOAA reanalysis model NCEP. The time-series covers the period of time in between 01/01/1979 and 31/12/2010. Figure 5 illustrates the wind rose for this period from which it can be observed that predominant direction is from eastern quadrant while prevailing winds comes from southern direction. 


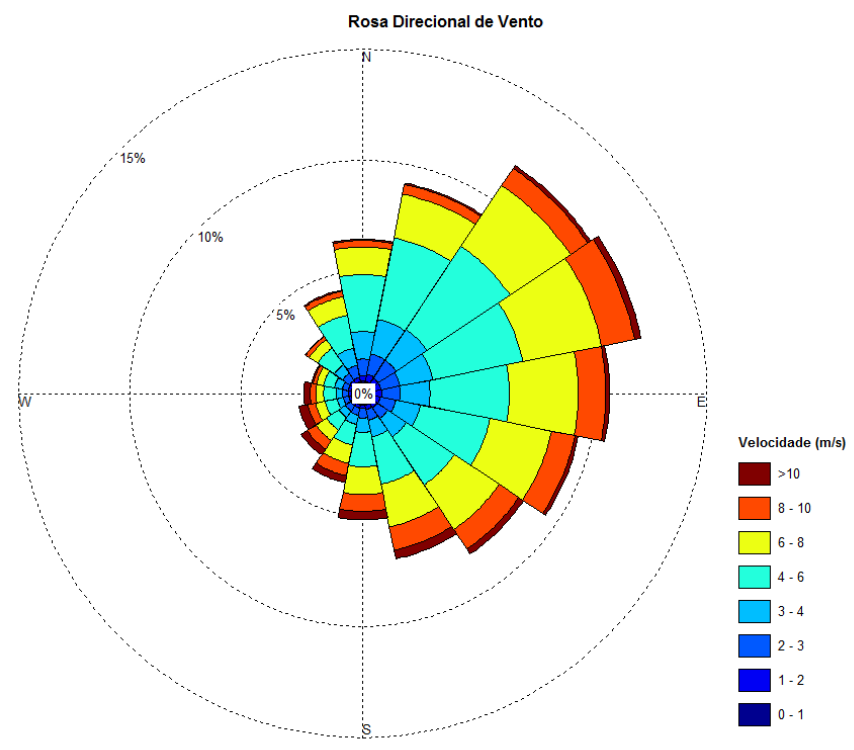

Figure 5. Wind rose from 1979 to 2010 , based on NCEP reanalysis model.

\section{Waves}

Deep-water wave information was obtained from NOAA's WAVEWATCH III (WWIII) forecasts. These forecasts were based on wave models that cover several study areas, including a worldwide domain. The selected hindcast node from which information was extracted was located at $26^{\circ} 30^{\prime} 00^{\prime \prime} \mathrm{S}$ and $047^{\circ} 15^{\prime} 00^{\prime \prime} \mathrm{W}$, WGS 84 (near the continental shelf slope). The wave data was extracted at this location due to the limitations of the WAVEWATCH model, which did not address conditions where the waves were strongly depth-limited, such as shallow or intermediate depth areas. From the wave rose, presented in Figure 6, it can be noticed that waves approaching from southern direction dominated the record (over 30\%), which together with waves from the southeastern direction are also the most energetic ones, with most of the occurrences of waves with significant wave height above $3 \mathrm{~m}$.

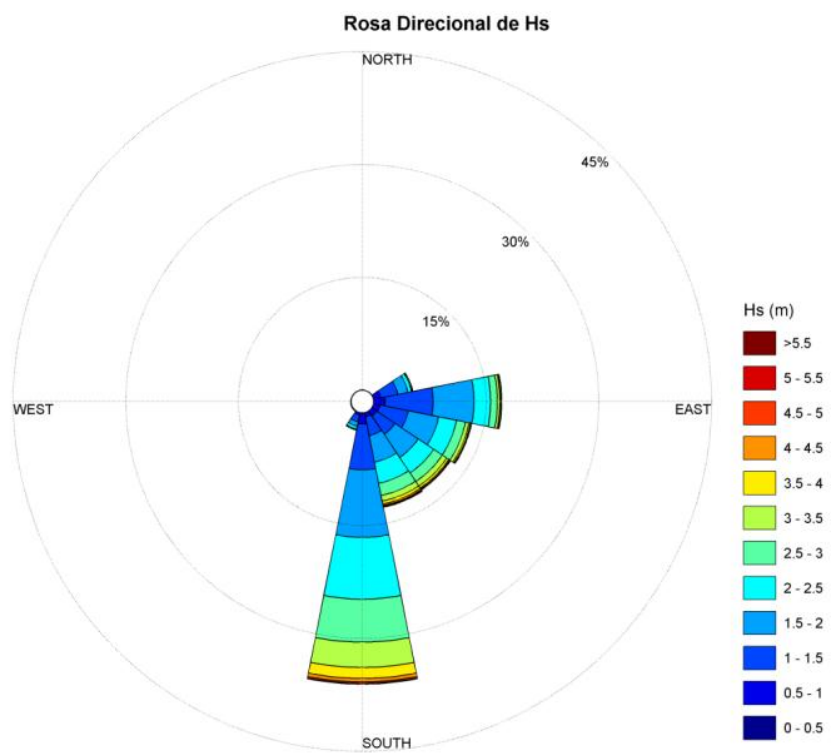

Figure 6. Wave rose from 1997 to 2010 , based on NOAA WaveWatch III global model. 


\section{Tides}

Tide data was obtained from FEMAR table of harmonic constituents for Ilha da Paz station. The tide in Babitonga Bay is semidiurnal with diurnal inequalities under micro-tidal regime. The average tidal range is $0.85 \mathrm{~m}$ reaching the maximum of $1.28 \mathrm{~m}$ (Truccolo \& Schettini, 1999).

\section{Bathymetry}

The bathymetry used for creating the actual scenario was extracted from detailed bathymetric surveys provided by São Francisco do Sul Port Administration and from recent bathymetric survey performed by Shaw Brasil. For the areas not covered by the surveys and for recreating the past scenarios nautical charts were used.

\section{Sediment}

The sediment characteristics were obtained through sedimentary analysis of 30 samples collected along the study area for this purpose. 15 samples were located on the channel adjacencies and 15 distributed over the beach and ebb-shoal. Results indicated that the sediment is composed primarily by fine sand (d50 in between 0.119 and $0.251 \mathrm{~mm}$ ) with very low percentage of mud (1 to $5 \%$ ).

\section{MODEL CALIBRATION}

Five different numerical grids were created with the purpose of representing the coastal processes on Babitonga Bay. Three wave grids were created to perform wave transformation from deep waters to shallow waters (Figure 7 - left panel), and two other grids were created to reproduce the hydrodynamic and morphologic patterns of Babitonga Bay (Figure 7 - right panel). The most refined flow/morphology grid was forced with data from the coarser grid, using and offline nesting technique.
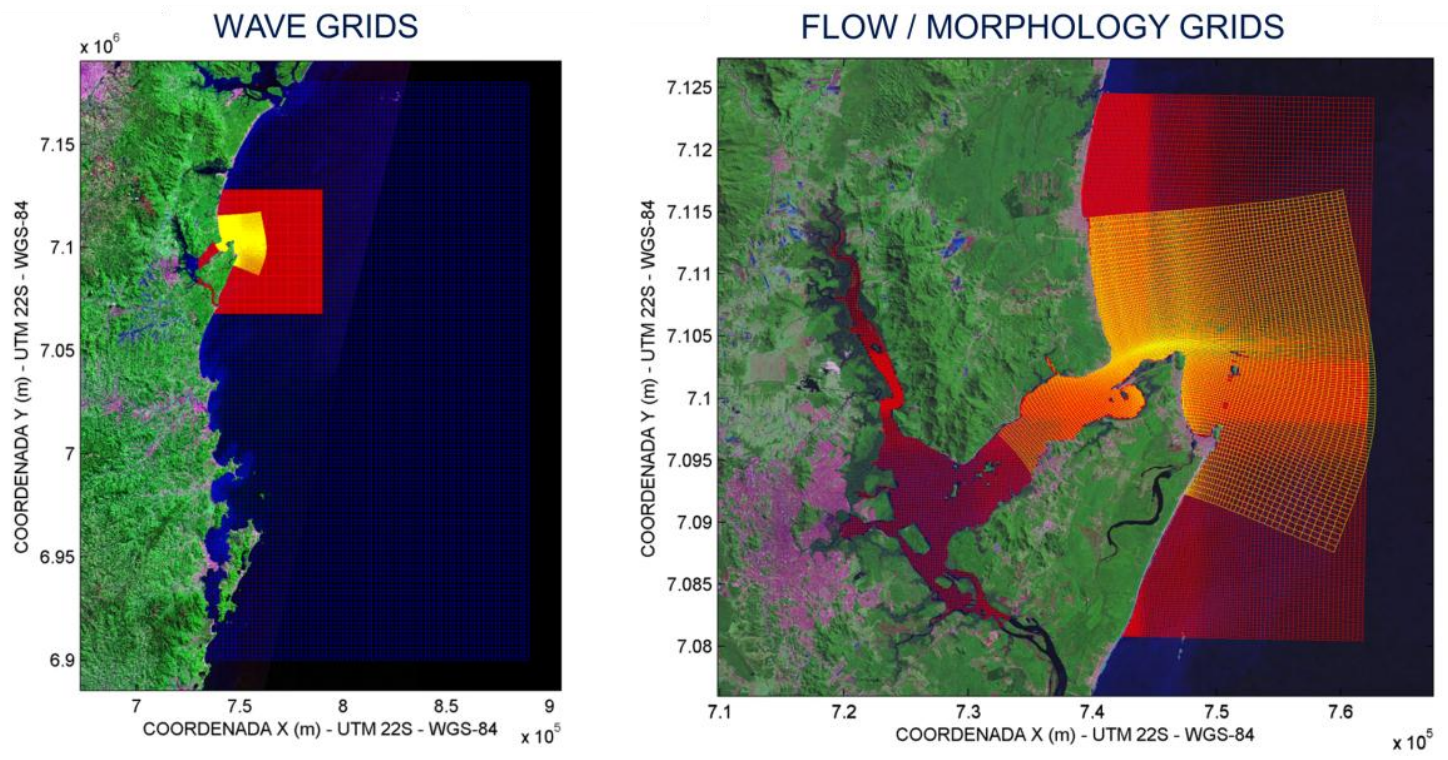

Figure 7. Wave and flow/morphology grids used in Delft3D.

The hydrodynamic and wave models were calibrated using 2 different sets of data. The first one was obtained on the literature. Amorin et. al (2006) collected tidal data on the study area between $21 / 02 / 2003$ and 28/03/2003. The second set of data was performed by Shaw Brasil and included current, waves and tide measurements between 14/06/2011 and 29/06/2011 with the use of one ADCP installed on the nearshore, at approximately $12 \mathrm{~m}$ of water.

The calibration models were forced using as boundary conditions the time-series of offshore waves and winds as well as the harmonic constituents. The time series obtained from the model results for the same period of time and geographic location were compared against the measured data. Figure 8 and 9 illustrate the good agreement between measured and modeled data.

The morphologic calibration was performed comparing measured and modeled sea-bed changes between 2005 and 2008, in a period of 2.2 years. This period was selected because there were none 
dredging activities within it, allowing a good estimate of the channel sedimentation rates. Because long term simulation with brute-force (i.e. time-series) input would result in high computation and time demands the Morfac approach was herein used as described in Lesser et al (2004) and Benedet and List (2008). Using this approach, 36 representative wave cases were selected based on the wave energy flux; the tides were schematized in a way that all wave cases are simulated over an equal tide cycle; and finally the resulting morphologic changes were multiplied by a factor (morfac) based on the frequency of occurrence of each case. The model was set to represent 2.5 years of morphological evolution. Results from morphologic calibration are presented on Figure 10. Note that the overall patterns with similar magnitudes are captured within the model. Simulated sedimentation rates were slightly smaller than measured rates, with $13 \%$ of underestimation.
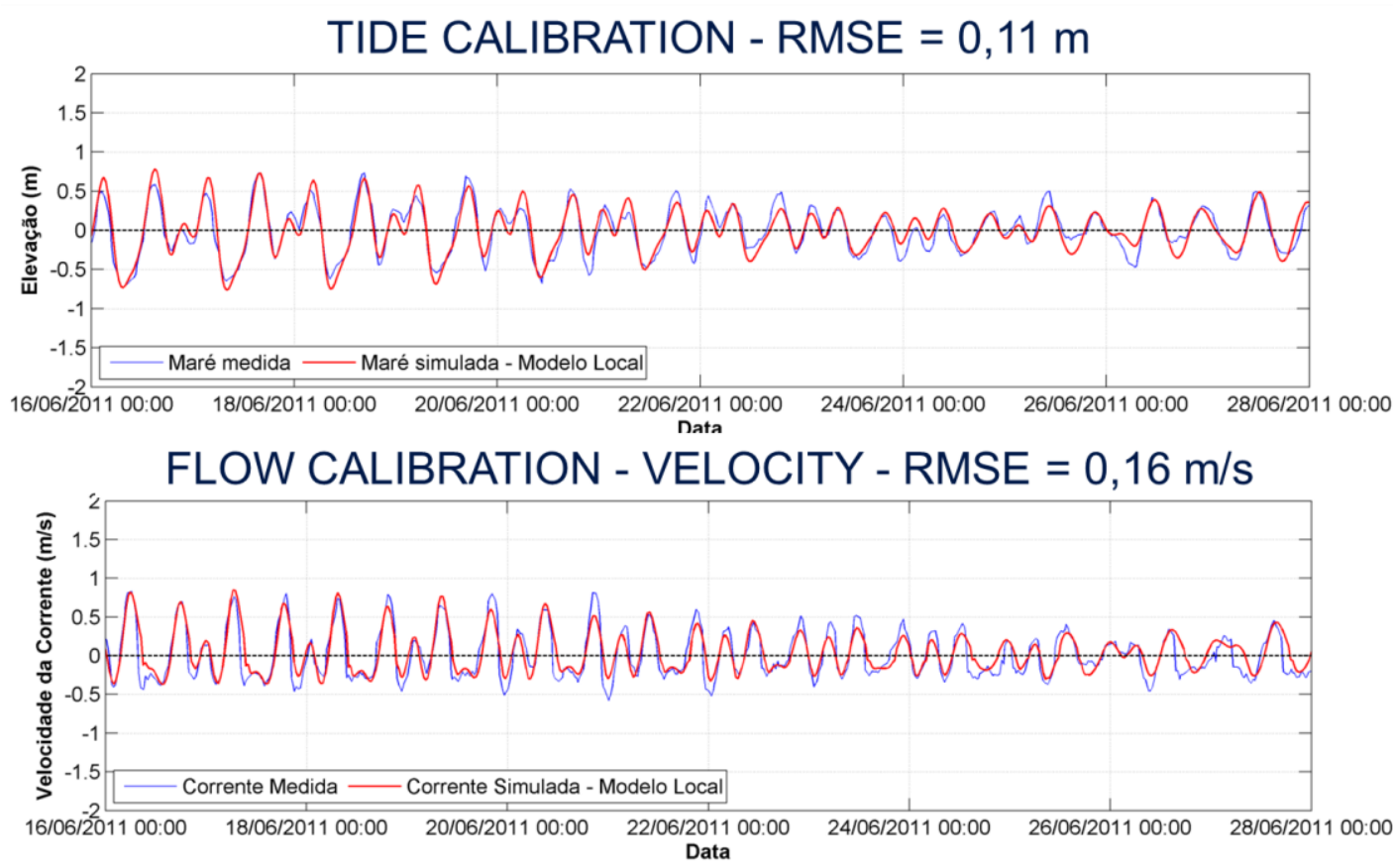

Figure 8. Hydrodynamics model calibration for water level (upper panel) and flow velocity (lower panel). Positive flow velocities denote ebb currents and negative velocities denote flood currents.

\author{
WAVE CALIBRATION - Hs \\ RMSE With Windgrowth $=0,22 \mathrm{~m}$ \\ RMSE Without Windgrowth $=0,46 \mathrm{~m}$
}

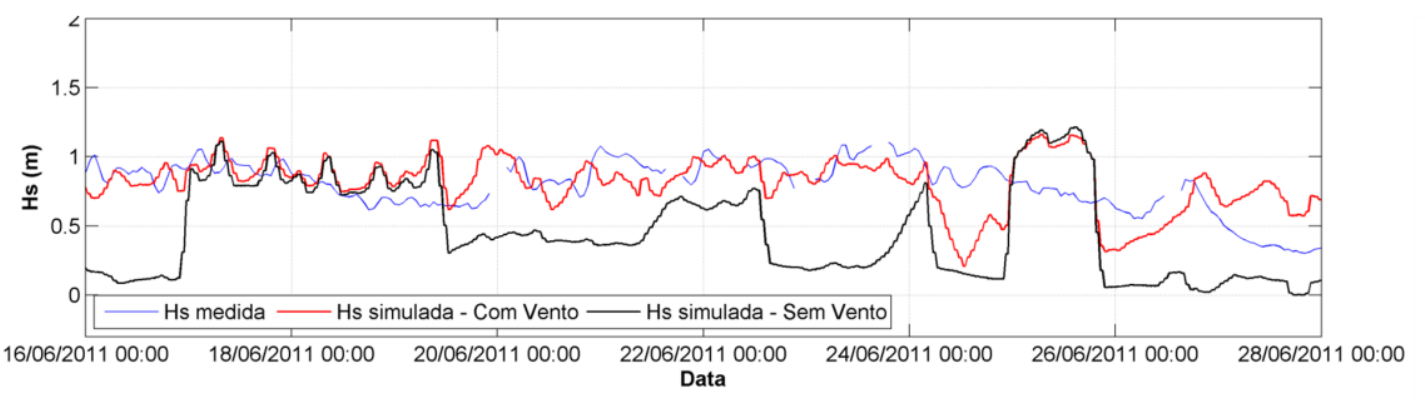

Figure 9. Wave model calibration for significant wave height. The importance of activating windgrowth in SWAN model for the model calibration can be observed. 

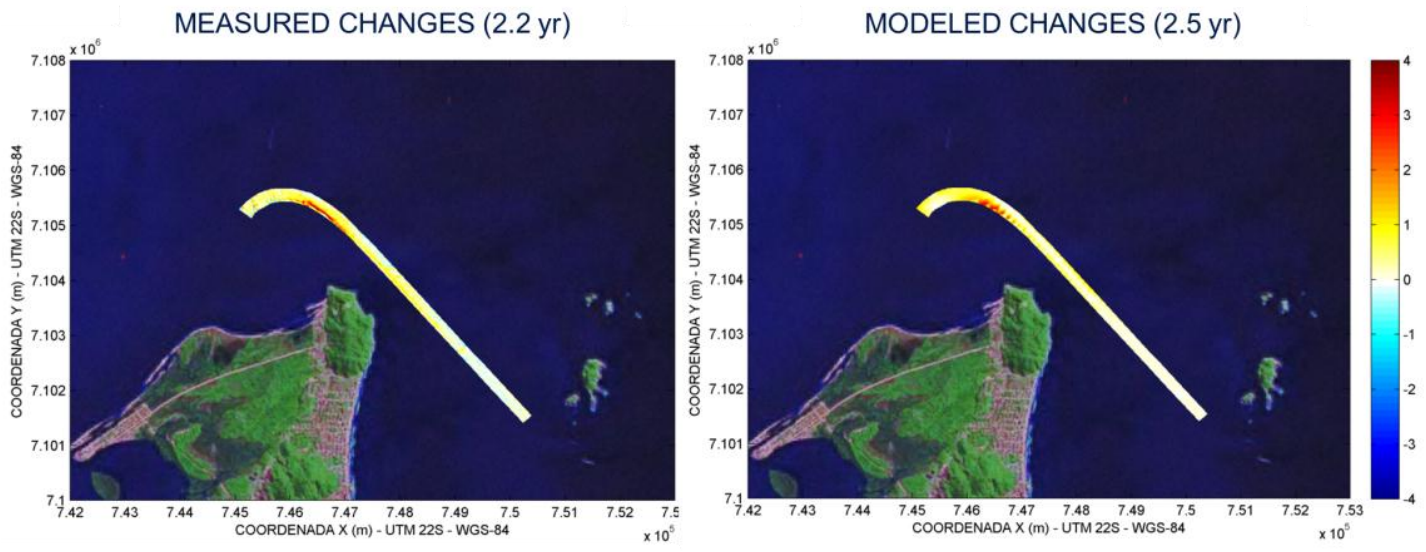

Figure 10. Morphodynamic model calibration, comparing morphology changes (in meters). It can be observed that the overall pattern of sedimentation produced by the model (right panel) is in good agreement with the measured morphology changes (left panel).

\section{CHANNEL IMPACT ASSESSMENT}

In order to estimate the impact on the Itapoá beaches generated from dredging and deepening the navigation channel of São Francisco do Sul port, 10-year morphodynamic simulations were performed. Three different scenarios were compared:

-Pre-dredging scenario, considering natural evolution of the beach, using 1941 nautical chart bathymetry as input;

- $10 \mathrm{~m}$ channel scenario, considering the channel dredged and maintained at $10 \mathrm{~m}$ depth, over the pre-dredging bathymetry;

-13 m channel scenario, considering the dredged and maintained at $13 \mathrm{~m}$ depth, over the predredging bathymetry.

The initial bathymetry interpolated on the numerical grid for each of the considered scenarios is presented in Figure 11. On the channel scenario simulations, the navigation channel depth was maintained constant during the simulation, using the dredge and dump feature of Delft3D, in order to simulate maintenance dredging operations. The volume of sediment that is deposited on the channel and makes it shallower than the dredging depth is automatically "dredged" in the model bathymetry and dumped on the dumping area. 


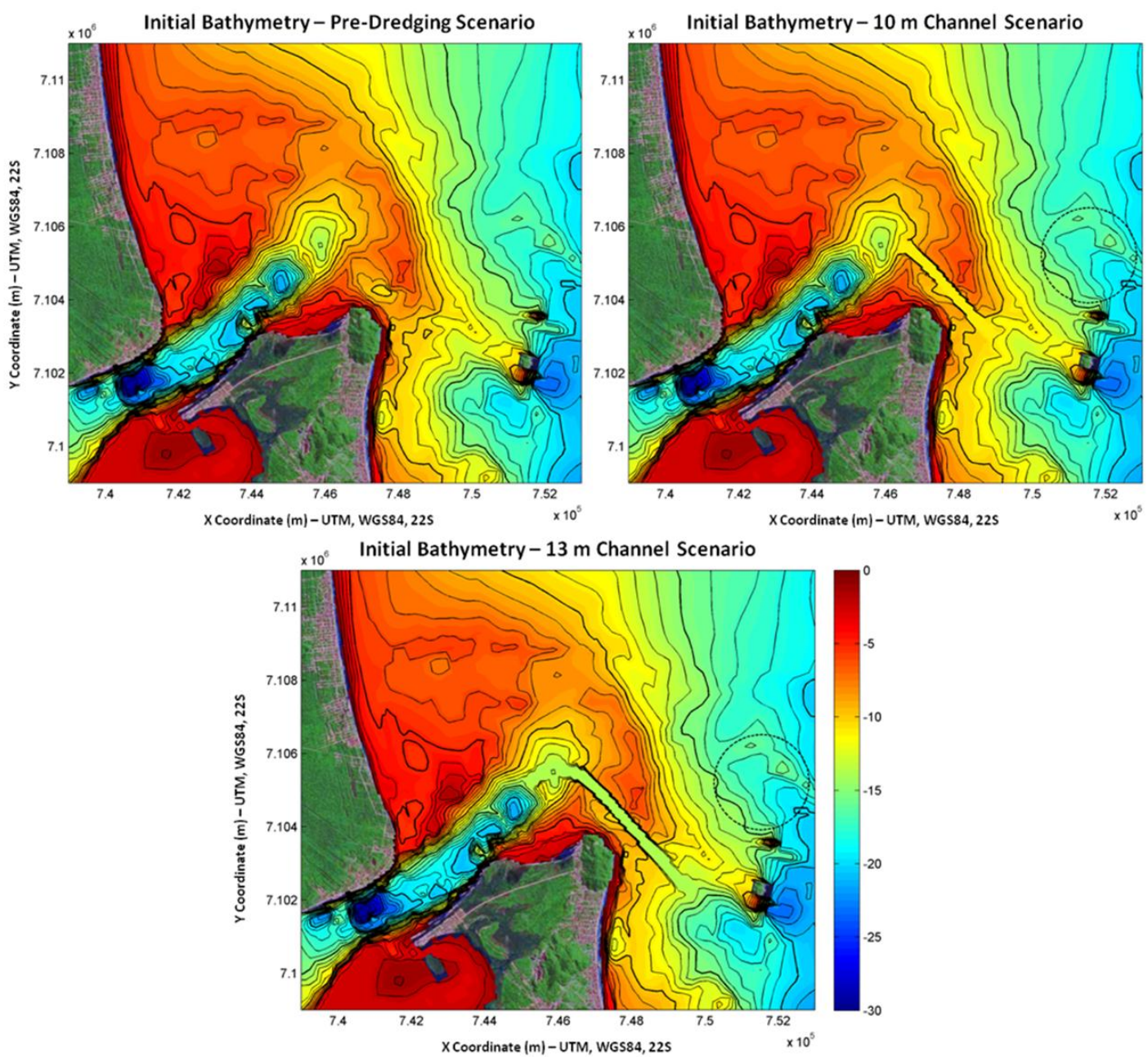

Figure 11. Initial bathymetry of the scenarios simulated for the channel impact assessment.

\section{RESULTS}

The channel impact assessment was performed comparing the results from the $10 \mathrm{~m}$ and $13 \mathrm{~m}$ channel scenarios with the results of the pre-dredging scenario. Evaluation of the results was subdivided into two sections: Impacts on wave propagation (mean energy flux), and on the net sediment transport (inlet sediment bypass).

\section{Impacts on wave propagation}

Impacts on wave propagation were estimated in terms of variation of the mean energy flux. Results are shown on Figure 12. It was noticed that by introducing the $10 \mathrm{~m}$ deep channel reduced the mean energy flux near by the beach west of the channel in the order of $2 \%$, and increased the energy northward in the order of 2 to $6 \%$, however the changes do not reach the beach. When comparing results from the $13 \mathrm{~m}$ channel it is perceptible that the differences are more expressive, especially on the ebb-shoal region and that the impacts reach the beach. 

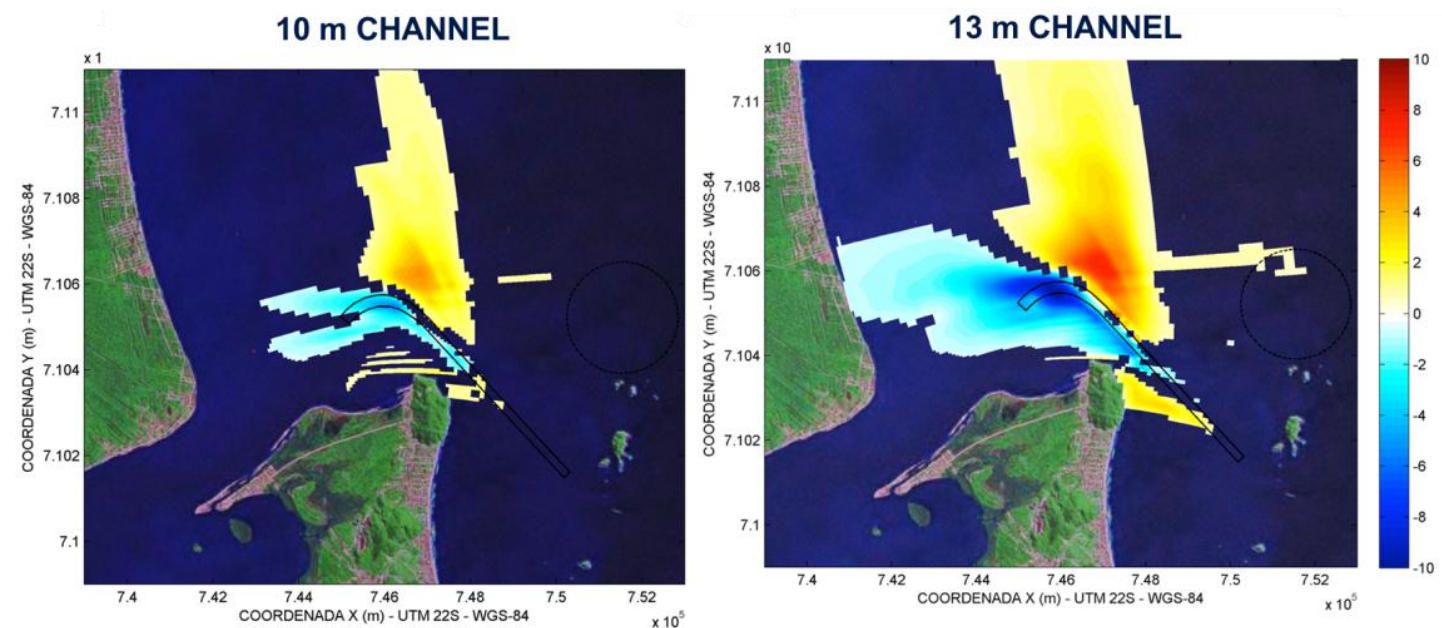

Figure 12. Channel impacts on wave propagation. Percentage changes in mean energy flux, relative to the pre-dredging scenario.

\section{Impacts on net sediment transport}

In order to evaluate the impacts on inlet sediment bypass, the net transport results of the three simulated scenarios were compared along a cross section located on the northern end of the channel and which extent covers the area where the sediment transport is northward directed (Figure 13). Thus it was possible to observe the effects of channel dredging and maintenance on the amount of sediment that would bypass the inlet towards the northern lobe of the ebb shoal.

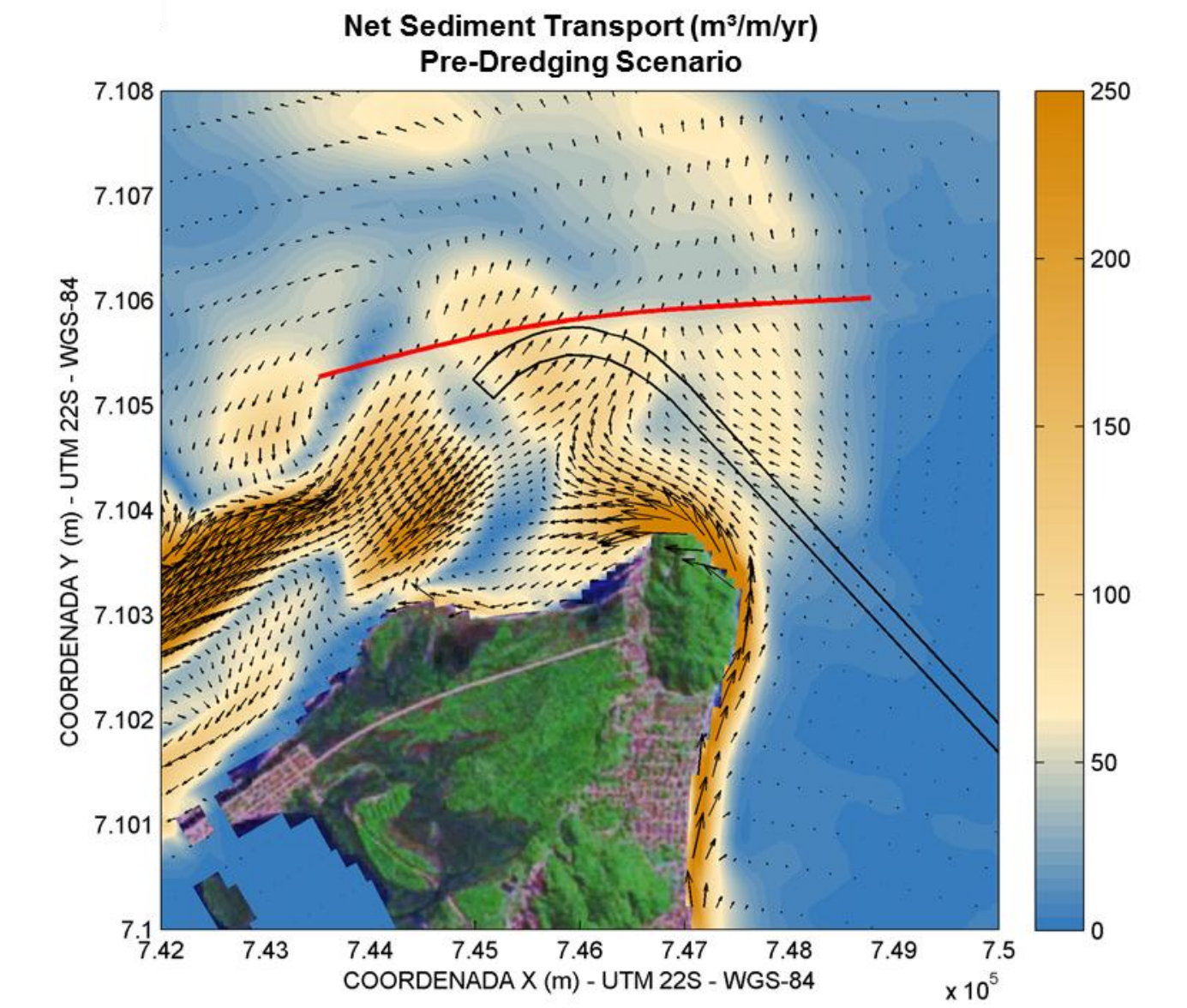

Figure 13. Net sediment transport results $\left(\mathrm{m}^{3} / \mathrm{m} / \mathrm{yr}\right.$.) and the location of the cross-section adopted for the estimation of the bypass volume (in red). 
The total sediment transport from the channel scenarios integrated along the cross section were compared with the transport observed on the pre-dredging scenario. Thus, it was possible to obtain the impact associated with each channel. In order to estimate the net impact along the 30 years of dredging operations, a weighted averaged considering the approximate period that the channel was maintained at each depth was calculated, as described in the following equation:

$$
\text { Net Impact }=\frac{(10 \mathrm{~m} \text { Channel Impact } \times 20 \mathrm{yr})+(13 \mathrm{~m} \text { Channel Impact } \times 10 \mathrm{yr})}{30 \mathrm{yr}}
$$

The results of impacts on sediment bypass are presented on Table 2, below.

\begin{tabular}{|c|c|}
\hline $\begin{array}{l}\text { Table 2. Results of inlet sediment bypass impact for each } \\
\text { channel scenario and net impact. }\end{array}$ \\
\hline Scenario & $\begin{array}{l}\text { Bypass Volume Change (relative to } \\
\text { pre-dredging scenario) }\end{array}$ \\
\hline 10 m Channel & $-9.4 \%$ \\
\hline 13 m Channel & $-20.8 \%$ \\
\hline Net Impact & $-13.2 \%$ \\
\hline
\end{tabular}

\section{DISCUSSION ON CHANNEL IMPACTS}

Based on numerical modeling results, a conceptual sediment model of the sedimentary dynamics of the study area was developed. Under natural conditions (pre-dredging scenario), the sediment transported alongshore on the beaches of the east coast of São Francisco do Sul island bypass the headlands of the beaches on the northern coast and reaches the inlet. Part of the sediment bypasses the inlet via the southern lobe of the ebb shoal, towards the northern lobe. The other part of the sediment is transported into the channel and may be transported inward of the bay or offshore, to the ebb shoal. The sediment that is transported to the ebb shoal and bypasses the inlet is slowly transported into the beach, where a reversal on the sediment transport direction is present. Part of the sediment is carried back into the channel, closing a cycle, and part is transported to the northern beaches, following the littoral drift. As observed in the modeling results, the dredging operations have directly influenced the sediment bypass towards the northern lobe of the ebb shoal (represented on Figure 14 by the arrow that crosses the channel), promoting a reduction of $13.20 \%$ on the amount of sediment that would be, afterwards, transported towards the beach.

Analyzing the results of 10-years morphodynamic simulations, it was possible to observe that the channel promoted the deepening of the southern lobe of the ebb shoal, due to the reduction of the bypass volume and also due to the increase in wave energy northward of the channel. This indicates that other long term effects may have occurred, due to morphodynamic feedbacks (i.e. changes on ebb shoal morphology affects the wave propagation, that promotes changes on sediment transport and ebb shoal morphology, and so on). Angulo (1993) indicates that natural variations on ebb shoal morphology promote direct effects on the adjacent beaches, corroborating with this hypothesis. However, as there is a lack of bathymetric data of the ebb shoal along the time, this hypothesis cannot be confirmed or denied, since it is difficult to hindcast the ebb shoal evolution without measured data.

The shoreline change analysis indicates that Itapoá beach is highly dynamic, and was dynamic even before the dredging operations started. In addition to that, erosive processes are observed in most of the beaches of the northern coast of Santa Catarina State, especially on urbanized areas. Thus, it cannot be inferred that all the erosion observed on Itapoá is due to the dredging operations, even observing that it may have had a contribution to the process.

Regardless of the amount of channel dredging contribution to the coastal erosion, the impacts can be mitigated by artificially bypassing the dredged sediment, instead of dumping it offshore. To evaluate that, beneficial sediment disposal strategies were studied, as presented in the next section. 


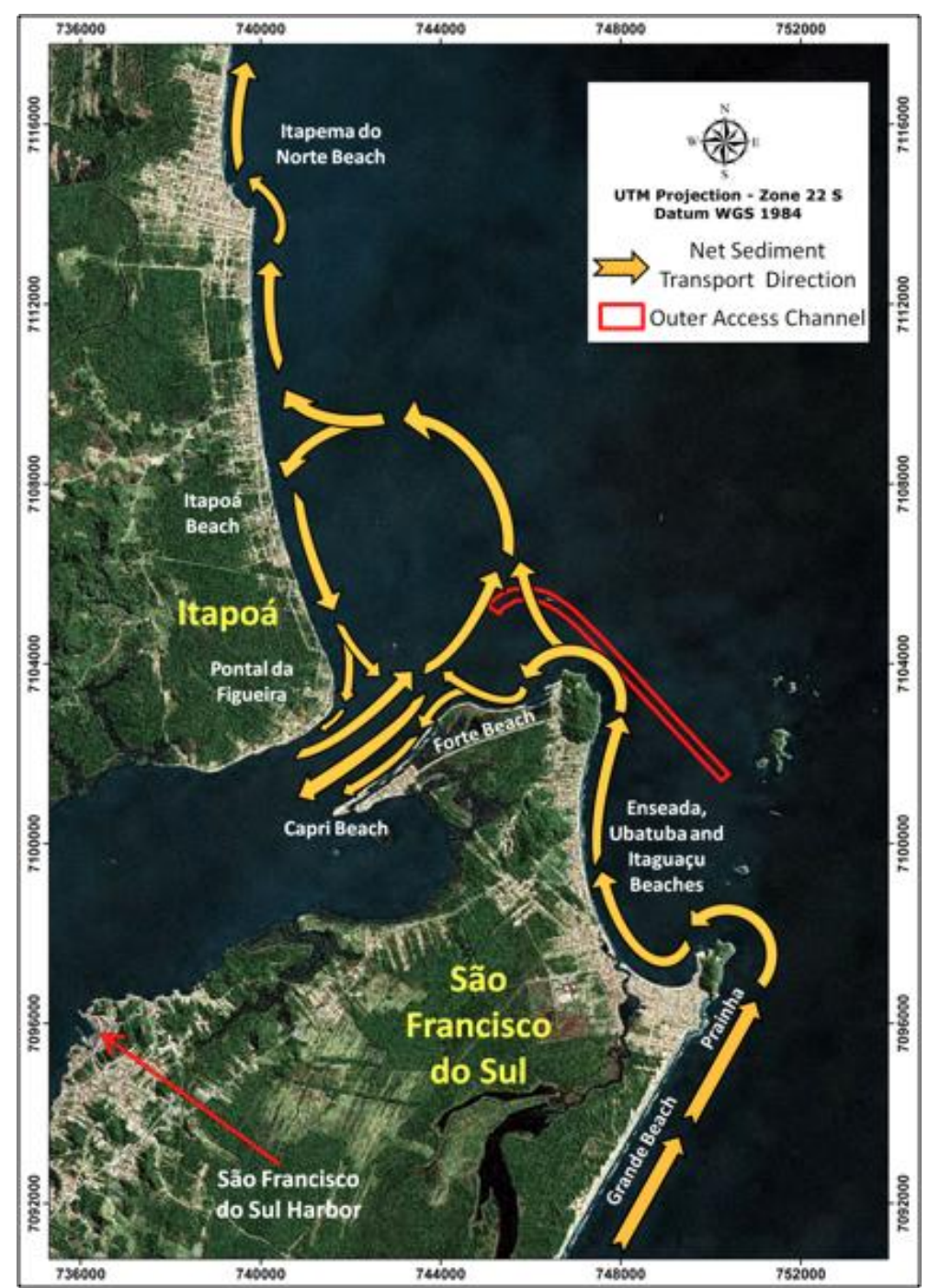

Figure 14. Conceptual model of the sedimentary dynamics of the study area. Arrow size and width do not represent sediment transport magnitude, only direction.

\section{LOOKING FOR THE FUTURE: MITIGATION ALTERNATIVES}

Taking in consideration that the channel dredging activities have contributed to the erosion problem of the downdrift beaches in addition to the fact that the dredged sediment composition is similar to the beach sediment, two mitigation alternatives of beneficial sediment disposal were proposed and evaluated with the use of the dredge and dump feature of Delft3D:

-Alternative 1: Beach nourishment along Itapoá beaches, dumping the dredged sediment directly onto the beach;

-Alternative 2: Disposal of dredged sand onto the northern lobe of the ebb-shoal between the isobaths of $7 \mathrm{~m}$ and $9 \mathrm{~m}$.

The location of the dumping areas is presented in Figure 15. The results of these models were compared with the simulation of the present scenario (with channel dredged at $14 \mathrm{~m}$ depth, using an offshore dumping area). Differences on the final morphology (after 10 year morphodynamic simulations) of the two alternatives and the present scenario are shown in Figure 16. It can be observed that beach disposal promoted direct benefits to the beach, since the volume was maintained on the beach. The ebb shoal disposal did not promote direct benefits to the beach within the evaluated timeframe, since the sediment did not reach the beach. However, it was kept on the coastal system, being transported towards the beach and may promote benefits in larger timeframes. 
Based on those results and analyzing the dredging history, beach disposal was recommended for dredging operations over $400.000 \mathrm{~m}^{3}$, based on cost-benefit analysis. For smaller dredging operations, ebb shoal disposal was recommended.

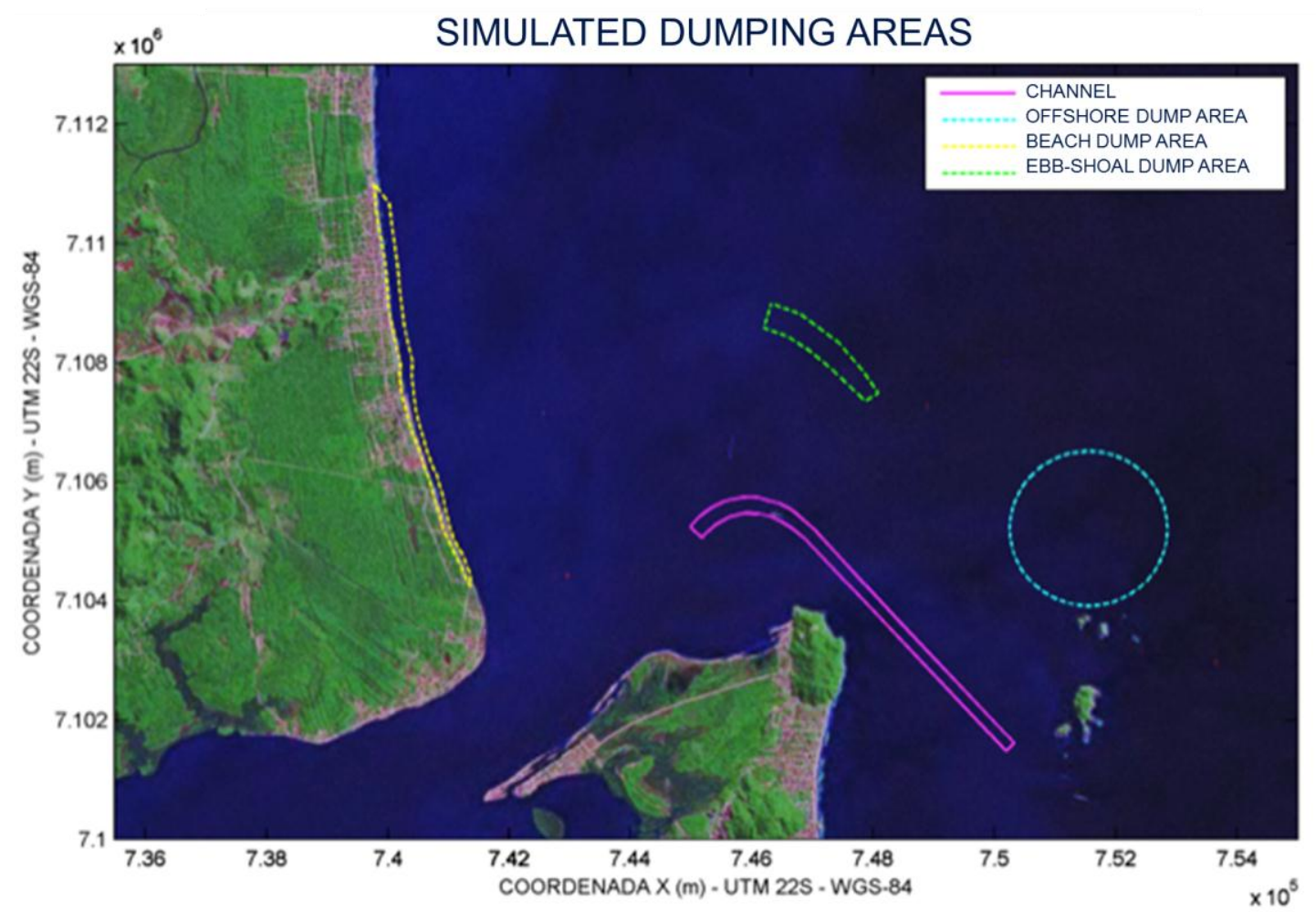

Figure 15. Beneficial dumping areas evaluated. Beach disposal is presented in yellow, ebb shoal disposal in green and the currently used offshore dumping area in blue.
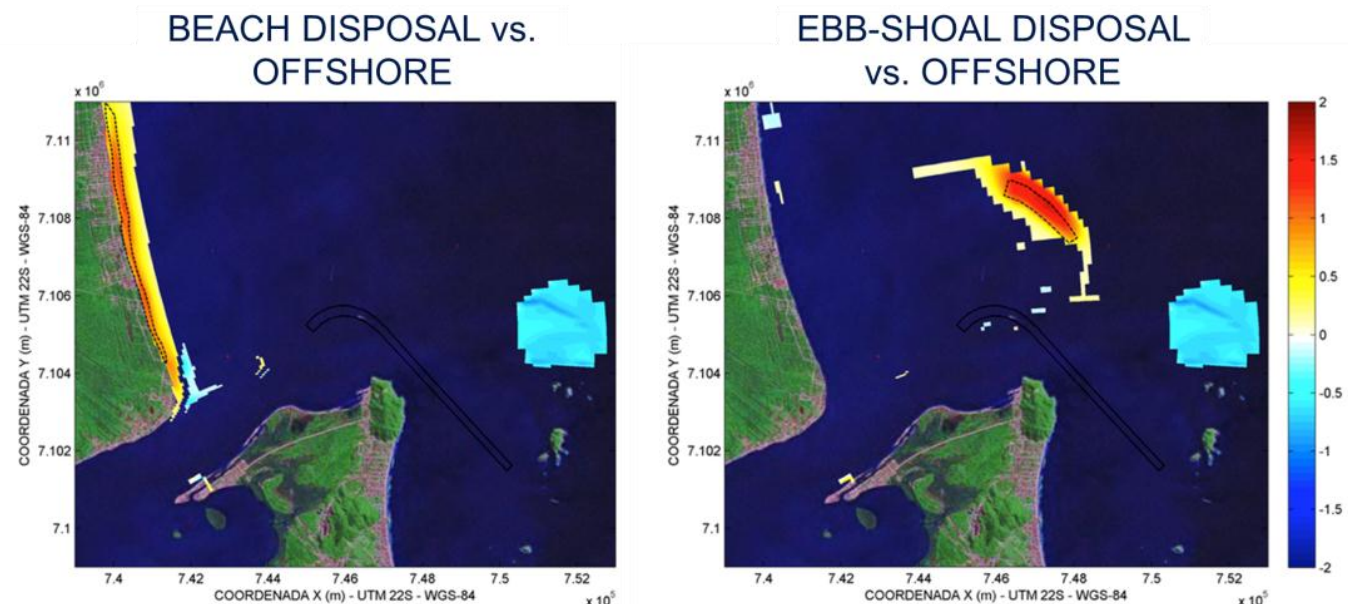

Figure 16. Beneficial dumping areas evaluated. Beach disposal is presented in yellow, ebb shoal disposal in green and the currently used offshore dumping area in blue.

\section{FINAL CONSIDERATIONS}

A morphodynamic numerical modeling study was conducted in order to identify the effects of channel dredging and maintenance on the erosion of Itapoá beach and propose solutions to mitigate the erosion effects. The following conclusions can be made, based on the modeling results:

- Channel dredging and maintenance have reduced $13 \%$ of ebb-shoal sediment bypass;

- Changes on wave propagation patterns may have promoted changes on ebb-shoal morphology; 
- Other beaches in the region, not directly influenced by the channel, also experience erosion;

- Potential changes in bay tidal prism and coastal sediment supply may have contributed to the erosion;

- Due to the feedback effects of morphodynamic evolution, the exact amount of channel-induced erosion is hard to be determined.

- Using an offshore disposal area have removed more than 10 million $\mathrm{m}^{3}$ of sediments from the coastal system;

- Beach or ebb-shoal disposal areas would keep the sediment within the system;

- Beach disposal promotes direct benefits to the beach in a short timeframe;

- It was recommended for dredging operations over $400.000 \mathrm{~m}^{3}$.

- Ebb-shoal disposal does not benefits the beach within a 10 year timeframe;

- It was recommended for dredging operations below $400.000 \mathrm{~m}^{3}$.

\section{REFERENCES}

Amorin, J.C.C.; Elfrink, B.; Carvalho, J.L.B.; Casaroli, L.F.R. 2006. Diagnóstico dos estudos de circulação de água no Canal do Linguado e na Baía da Babitonga. Diagnóstico ambiental da Baía da Babitonga - Joinville. SC: UNIVILLE.

Angulo, R.J. 1993. Variações na configuração da linha de costa no Paraná nas últimas quatro décadas. Boletim Paranaense Geociências. Curitiba. 41:52-72.

Angulo, R.J.; Souza, M.C. de \& Lamour, M.R. 2006. Coastal Erosion Problems Induced by Dredging Activities in the Navigation Channel of Paranaguá and São Francisco do Sul Harbor, Southern Brazil. Journal of Coastal Research, SI 39 (Proccendigs of the 8th International Coastal Symposium), 1801 - 1803. Itajaí, SC, Brazil, ISSN 0749-0208.

Benedet, L. B. \& List, J. H. 2008. Evaluation of the Physical Process Controlling Beach Changes Adjacent to Nearshore Dredge Pits. Coastal Engineering, Vol. 55 (12), 1224-1236.

DNIT/IME. 2004. Estudos Ambientais da Baía da Babitonga - Canal do Linguado. Technical Report.

INPH. 1985. Relatório de Análise das Alternativas de Reabertura do Canal do Linguado Conjugado com melhorias de sua Barra. Estudos de Reabertura do Canal do Linguado. Technical Report.

LECOST - Laboratório de Estudos Costeiros. 2002. Diagnóstico Sobre os Problemas de Erosão Costeira no Município de Itapoá, Litoral Norte do Estado de Santa Catarina. Technical Report.

Lesser, G.R.; Roelvink. J.A.; Van Kester, J.A.T.M. \& Stelling, G.S. 2004. Development and Validation of a Three-Dimensional Morphological Model. Coastal Engineering. Vol. 51. P. 883915.

RIOINTERPORT/ACQUAPLAN. 2007. Diagnóstico da Evolução da Linha de Costa na Região Adjacente às Instalações do Porto de Itapoá, Município de Itapoá - SC. Technical Report.

Souza, M.C. 1999. Mapeamento da Planície Costeira e Morfologia e Dinâmica das Praias do Município de Itapoá, Estado de Santa Catarina: Subsídios à Ocupação. Universidade Federal do Paraná, Dissertação de Mestrado.

Truccolo. E.C. \& Schettini. C.A.F. 1999. Marés Astronômicas na Baía da Babitonga, SC. Notas Técnicas FACIMAR. 3. 57-66. 